Until 1920, Squire processed materials, campaigned to have some staff assigned to him, and urged the printing of a music catalog (which finally appeared in 1912). He gained the support of the administration and built the framework that his distinguished followers, W. C. Smith and King, would use in shaping the world's finest music library.

We may hope that Alec Hyatt King will complement the present volume with one that describes the work of Smith, as well as the major events and achievements of his own tenure.-Guy A. Marco, Library Development Consultants, Washington, D.C.

Lushington, Nolan, and Mills, Willis N., Jr.

Libraries Designed for Users: A Planning

Handbook. Syracuse, N.Y.: Gaylord Professional Publications, 1979. 289p. $\$ 22.50$ plus postage and handling. LC 78-27114. ISBN 0-915794-29-2.

This book is a definite contribution to the literature on library buildings. It is a book for all library planners, for academic and public librarians, and for special librarians, as well as for architects, engineers, and designers. The authors state early in the book that it is primarily for the design and planning of small to medium-size public libraries serving from 200 to 2,000 people per day. However, the information in the book is prepared in such an enlightening manner that it is beneficial to those planning large urban central library buildings, academic library buildings, or even school and special library rooms.

The authors declare what they believe to be the performance objectives for the readers of their book, which are that the reader should be able to "prepare a library improvement program," "recognize library functional relationships," "critique an existing library building," "interview and select an architect and consultant," "evaluate the work of a library design team," "evaluate proposed library sites," "critique schematic designs for libraries," and "improve energy conservation, graphics, seating, and lighting in existing libraries as well as in library plans."

From there the authors proceed in a simple, straightforward, factual arrangement of their information. For example, lists are often used, such as, where to purchase materials, information on suppliers and manufacturers, and twenty-five energy conservation tips. Further, the whole work is liberally supplied with photographs and line drawings to express design features. The book ends with a selection of case studies of actual library space programs.

The book is clearly not an intellectual effort on the theory of library construction or space planning. On the other hand, it is a straightforward handbook on how to plan for library space utilization and how to design for functional use of space.

While generally the work consists of practical information, it is noted, however, that if not directly in the text, then generally through illustration and photographs, unusually high priced or expensive furniture is specified. On the other hand, general practitioners using this book should be able to discern this for themselves.

The book could have been more efficiently produced. Unusually wide margins are used (3/4-inch inner margin and $2 \frac{1}{2}$-inch outer margin). Also as an example of waste space, page 264 contains a simple two-line caption for a drawing on the facing page 265. Thus, through some economy of space in the layout of the book, the information could have been presented in about 25 percent less space than was used. On the other hand, the format that was employed does add to the attractiveness of the book and its simple use.

On the whole this book is valuable to all library planners and should be added to the collection of any practicing librarian or library collecting information on library buildings.-Hal B. Schell, University of Cincinnati, Cincinnati, Ohio.

Woods, L. B. A Decade of Censorship in America: The Threat to Classrooms and Libraries, 1966-1975. Metuchen, N.J.: Scarecrow, 1979. 183p. \$10. LC 7920960. ISBN 0-8108-1260-6.

In this book, which covers censorship attempts in the United States over a ten-year period, the author, L. B. Woods, presents evidence showing that censorship is on the increase. Woods gives the following reasons for having done the study. The principal reason, he says, was that empirical knowl- 
edge relating to censorship is sketchy and often is based on opinion, not fact. More data are needed by persons who have to be involved, especially in subject areas likely to come under attack in schools and libraries. A second reason for the study was due to the U.S. Supreme Court decision of June 21,1973 , that changed interpretations of the First Amendment relating to obscenity regulations. The third reason was based on the author's conviction that censorship is much more prevalent than many librarians and educators believe and that specific facts might help them if they should ever be faced with censorship issues.

A great deal of quantitative data about censorship in the United States are presented by Woods in an effort to answer nine specific questions. These questions, in brief form, are: (1) When did the censorship attempts occur? (2) Where did they occur? (3) How many items were censored? (4) What formats of materials were censored? (5) What types of educational institutions were affected by the censorship attempts? (6) What were the titles of the censored mate-

\section{The Economics of Online Bibliographic Searching: Costs and Cost Justifications}

\section{by William Saftady}

Describes the services currently available and what it takes in terms of equipment, personnel, and training for a library search service to become operational.

Saffady's unique contribution is an economic analysis of the various options, including cost comparisons between manual and machine-assisted searching.

In Library Technology Reports September/October 1979 issue Volume 15 Number 5

Single issue price $\$ 40.00$

\section{Library Technology Reports} American Library Association 50 East Huron Street, Chicago, IL 60611 rials? (7) What were the sources of the censorship attempts? (8) What were the reasons for the censorship attempts? (9) What were the final dispositions of the censorship attempts?

Several interesting facts emerged in the study. One was that schools accounted for 62 percent of all educational censorship, with more than two-thirds of this on the high school level. The author noted that "public libraries were less censored than colleges and universities, but more censored than other school levels or junior colleges." The most often censored title was Catcher in the Rye, and the second most often censored was Soul on Ice. Many other interesting facts are given on the various topics, and tables are included to document the findings.

This is a well-written, carefully prepared study of censorship in America between the years 1966 and 1975. It should be of invaluable assistance to anyone who has to deal with censorship problems.-Martha Boaz, University of Southern California, Los Angeles.

Hernon, Peter. Use of Government Publications by Social Scientists. Libraries and Librarianship: An International Series. Norwood, N.J.: Ablex Publishing Corp., 1979. 173p. \$16.95. LC 79-16144. ISBN 0-89391-024-4.

The first book-length use study of government publications, Use of Government Publications by Social Scientists, examines the use and nonuse of federal, state, local, foreign, and international documents by historians, sociologists, political scientists, and economists. In addition, Hernon investigates the effect of library characteristics, such as organization, collection arrangement, etc., on the use of documents. The study is based on questionnaires and interviews administered to faculty and librarians at seventeen public and private institutions offering bachelor's through doctoral programs.

Hernon's findings are both enlightening and of tremendous practical value. Social scientists, excluding historians, rely primarily on current publications. All social scientists use only a relatively few types of documents, such as statistical publications, 